\title{
The Joy of Kierkegaard: Essays on Kierkegaard as a Biblical Reader, by Hugh Pyper
}

BibleWorld | Sheffield: Equinox, 20 I I | xvi + I68 pages | ISBN: 978-I-84553-27I-O (hardback) £60.00| ISBN: 978-I-84553272-7 (softback) £19.99

To get to grips with Pyper's book it is essential to appreciate the story of its composition. Written over nearly twenty years, The Joy of Kierkegaard consists of eleven short and fairly discrete discussions of the Dane's relationship with the Bible, theology, philosophy and morality. The essays have for the most part been left in the form in which they were originally published and, as stated in the preface, the main purpose of the book is to now bring these works together for the convenience of readers. Having said this, it should be observed that not every essay has previously been accessible. For example, the provocative and at times disturbing exploration of Kierkegaard's engagement with the issue of how one should follow ethically questionable scriptural commands (chapter 4) has not been published before, having previously only taken the form of a 2003 conference paper.

Although the essays do on occasions deal with such technical issues as specific grammatical points within biblical texts and Kierkegaard's relationship with them, Pyper's book is one that far more readily steps back and attempts to tackle much broader complexities of the human condition. How can a realistic appreciation of despair become a foundation for joy? How can humanity face up to the nature of death? How can forgiveness take place without forgetting the sin committed? It is such questions that occupy the book, and Pyper takes the view that one mode by which we might engage with them is to explore Kierkegaard's use of the Bible.

The depth of The Joy of Kierkegaard is such that it will certainly find a receptive audience, but at times its fragmentary nature can be felt. One rather obvious point is that there is no neat progression of argument through the book. Despite the recurring themes, such as Kierkegaard's partial disagreements with Luther's biblical readings, each essay is a largely independent unit. Furthermore, on first reading there are some chapters where one very initially gets the sense of entering a conversation already begun elsewhere. Given that some of the essays were originally published in collections devoted to specific texts of Kierkegaard's, this is perhaps not especially surprising. Despite these 
mild caveats, there are nonetheless no parts of Pyper's book that ultimately fail to reward (and provoke) readers. Equipped with an awareness of what The Joy of Kierkegaard is, and is not, this is a text filled with ideas that linger in the mind long after its last words are read. What the book is not is a tidy and basic introduction for students entering into reflection on Kierkegaard's interpretations of the Bible. What the book does represent, however, is essential reading for those already broadly familiar with the field.

The one essay with which this characterisation rather falls down is in chapter 8. Focused on humour in Kierkegaard's Concluding Unscientific Postscript, there is little here for those interested in biblical reception to directly get hold of. Though no doubt of value for Kierkegaard scholars, it is the one section that does noticeably appear to drift away from the remit of the book's subtitle. Elsewhere, however, The Joy of Kierkegaard convincingly reaffirms that "whatever else he was, Kierkegaard was an engaged reader of the Bible" (8I). As well as taking on older approaches, such as Luther's interpretations of James's epistle, Kierkegaard's ways of engaging with biblical texts are shown to raise questions of method that continue to be very relevant to this day. Examining his relationship with Tobit, for example, Pyper demonstrates how Kierkegaard illuminated "the mismatch between what is written and what is read, between utterance and reception" (I 25-26). Closely related to this, Kierkegaard's doubts about historical-critical scholarship's ultimate significance are repeatedly highlighted. The kinds of foundational questions about humanity noted above are, it is proposed, unnecessarily disrupted by a focus upon the historicity of a text. Thus "to ask whether Adam is myth or history deflects us from seeing what in us is mirrored in Adam" (94). The attempt to unpick the origins of the Bible is, for Kierkegaard, to largely ask the wrong, or perhaps simply less interesting kinds of questions.

Despite covering an array of angles concerning Kierkegaard's view of the Bible, it should be reiterated that The Joy of Kierkegaard does not function as an introduction to the topic. One indication of this is the comparative lack of attention given to his famous treatment of the Akedah. Pyper's focus on Gen 22 is rather brief, one suspects, because over the last twenty years he has found new prompts for discussion by instead looking at Kierkegaard's other, less iconic, receptions of the Bible. The result is a collection of essays which, though not a polished whole, demands the attention of scholars in the field.

\author{
David C. Tollerton \\ Bangor University
}

